much gastric irritation, small doses of mercury with chalk, with morphia at bedtime, will be very useful. Alkalies, with the nitrate of potash, may be taken during the day. This, with a diet strictly confined in the first instance to broth and farinaceous articles, will generally effect recovery.

In the atonic variety, the bowels will be best regulated by the compound rhubarb pill, with the addition of one grain of the sulphate of iron; alkalies, with ammonia and chloric ether, will also be proper; and if the vomiting be very troublesome, with a tolerably clean tongue, bismuth in ten-grain doses, with chloric ether, will often act like a charm in giving relief. The bismuth lozenges of the British Pharmacopoia will be found very useful in private practice, as an auxiliary to the alkaline treatment.

In reference to tonics, I believe that, as a rule, even the mildest are better avoided during any stage of the treatment of the irritative form of this disease. In the second variety, however, where nervetone is so decidedly deficient, a judicious combination of small doses of steel, with ammonia and carbonate of potash, and a few minims (four to five) of the liquor strychniæ (Brit. Pharm.), will often be very beneficial.

Of stimulants for dyspeptic use, the best are, unquestionably, dry sherry, diluted with water; claret, in small quantity, and brandy well diluted. Of these, I believe the first to be the best; but claret often agrees exceedingly well, particularly if the patient be of a gouty predisposition.

In the irritative form of dyspepsia, all stimulants of this kind are, I believe, as a rule, better interdicted.

[To be continued.]

\section{EXCISION OF THE SCAPULA BY PROFESSOR MICHAUX OF LOUVAIN.}

From Notes by Gordon HaRdie, M.D., 73rd Regiment.

Louvain lies out of the direct route of Belgian travel, but will repay a visit in many ways. It has still the grave ecclesiastical air of a mediæval university town. Its histel-de-ville is the gem of municipal Gothic architecture in Europe, as highly finished as a châsse. The University has a very complete Faculty of $\mathrm{Me}$ dicine, a good hospital, and two excellent clinical professors in surgery and medicine.

The former, Professor Michaux, has an European reputation as a bold and skilful operator, especially in regard to excisions of the upper jaw and the extirpation of naso-pharyngeal polypi through the opening thus made. He has been led to adopt this operative process from his own experience, as well as from that of others, of the liability to relapse, if the polypus, with its various roots and insertions, be not wholly extirpated and freely cauterised with the redhot iron; as also from the impossibility, in many cases, of removing the tumour through any smaller opening. He, therefore, considers that "Resection of the upper jaw, to make way for the removal of large fibrous naso.pharyngeal polypi, with large and resisting roots and multiple ramifications, should be considered as the general method."

He has now performed this operation seven times, with complete success, and with an experience of many years immunity from relapse in the persons of the first two. The remainder have been operated on within the last four years; but were all known to be well and without relapse in December 1864 .

The credit of having been the first to perform this operation for the cure of naso-pharyngeal polypus, he gives to Professor Syme of Edinburgh, who, in 1832 , led the way.

At the time I visited Louvain, Professor Michaux had removed the upper jaw, for these and other causes, twenty-three times successfully, and once with a fatal result.

While there, in December last, I witnessed another formidable operation by Professor Michaux-excision of the scapula, in which also Professor Syme has led the way.

The patient was a lad, of about 15 years old, in whom a large enchondroma (as was supposed) occupied the greater part of the right scapula, extending closely up to the glenoid cavity. It was represented as having originated in the soft parts (?), and as having increased rapidly, the whole duration of the disease being only about six months. At the time t'. $\mathrm{He}$ lad entered the hospital, the tumour was closely incorporated with the scapula, and there seemed to be little chance of saving any part of the bone in removing the tumour.

A few days after entering the hospital, the lad underwent the operation. A crucial incision was made over the tumour, and the flaps quickly thrown back. The tumour was then divided to see if it could be detached from the scapula. This incision led to the most formidable hæmorrhage which occurred in the operation. It was arrested by means of plugs of charpie soaked in tincture of perchloride of iron. The last portion of the operation was done with the écraseur, dividing the parts in the vicinity of the joint without any further hæmorrhage. The lad bore the operation, which was prolonged from the necessity of administering stimulating enemata after the alarming hæmorrhage, very manfully.

I mentioned Professor Syme's operations to Professor Michaux, and sent him the brochure on my return. I have heard since from him that the wound was healing well, and that there was every prospect of the result proving successful. This was three weeks after the operation.

I stayed two hours only in Louvain after the operation, and did not learn what the nature of the tumour ultimately proved to be. I have no doubt that the case on recovery will be fully reported to the Belgian Royal Academy of Medicine.

“ Woman's Rights." A novel question has arisen at Oxford respecting the rights of lady governors of the Radcliffe Infirmary. At the October quarterly court, two ladies entered the room and tendered their votes on the election of a committee. This was an unprecedented circumstance, and the Master of University College, who presided on that occasion, would only receive the votes under protest. At the quarterly court last week, five ladies attended, and a long discussion took place, two propositions being submitted -one denying their right of attending, and the other proposing that counsel's opinion be taken on the question. The advocates of the former urged the usage of eighty years, and relied on a phrase in the rules-“ ladies subscribing as governors," as implying a distinction between them and the other sex. On the other side it was shown that ladies had the privilege of voting by proxy on certain occasions, and that proxies invariably conferred an additional and not a limited right. This view eventually prevailed, and it was consequently considered unnecessary to obtain a legal opinion. Professor Westwood has, however, since published a letter which, while admitting the right to vote of unmarried ladies, contends that this is a chattel interest, which in the case of married women is vested in their husbands. The dispute will, therefore, probably be revived. 


\section{LEEDS GENERAL INFIRMARY.}

Statistical Tables of the Operations performed from January to June, 1864, inclusive.

[Continued from page 59.]

Removal of Malignant Tumours.

\begin{tabular}{|c|c|c|c|c|c|c|}
\hline No. & $\begin{array}{l}\text { Sex } \\
\text { and } \\
\text { age. }\end{array}$ & Operator. & Nature of operation. & $\begin{array}{c}\text { Stay in } \\
\text { Hospital } \\
\text { after } \\
\text { operation. }\end{array}$ & Result. & Remarks. \\
\hline 1 & M. 54 & Mr. Nunneley & $\begin{array}{l}\text { Excision of epithe- } \\
\text { lioma from lower lip, } \\
\text { and plastic opera- } \\
\text { tion for restoration } \\
\text { of lip. }\end{array}$ & 24 dajs & $\begin{array}{l}\text { Recovery, with } \\
\text { very slight de- } \\
\text { formity. The } \\
\text { disease has re- } \\
\text { turned in the } \\
\text { cicatrix, and is } \\
\text { appearing in } \\
\text { the submental } \\
\text { glands. } \\
\text { Recovery. Re- }\end{array}$ & $\begin{array}{l}\text { The growth and ulceration were extensive, occupying } \\
\text { nearly the whole of the lower lip. There were no enlarged } \\
\text { glands. The whole was swept away by a semilunar inci- } \\
\text { sion; and a lower lip, made by drawing together the re- } \\
\text { maining lateral portions of lip, released by an incision on } \\
\text { either side, extending from the base of the wound outwards } \\
\text { through the cheeks to a distance of about an inch and a } \\
\text { half. The whole united, and a good lip resulted, by means } \\
\text { of which he was quite able to retain the saliva. } \\
\text { A small epithelial growth on the left half of the lower lip. }\end{array}$ \\
\hline & & 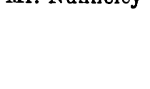 & lioma from lower lip. & & $\begin{array}{l}\text { turn in glands } \\
\text { beneath.jaw, } \\
\text { which were ex- } \\
\text { cised. }\end{array}$ & \\
\hline 3 & M. $\pi 2$ & Mr. S. Hey & $\begin{array}{l}\text { Removal of ence- } \\
\text { phaloid tumour from } \\
\text { parotid region. }\end{array}$ & 12 days & Recovery. & $\begin{array}{l}\text { An uicerated growth, the size of a pigeon's egg, sprung } \\
\text { from the deep tissues in the left parotid regibt. It had } \\
\text { commenced two years before. }\end{array}$ \\
\hline 4 & F. 31 & Mr. P. Teale & $\begin{array}{l}\text { Excision of scir. } \\
\text { rhus from left } \\
\text { breast. }\end{array}$ & 21 days & Recovery. & $\begin{array}{l}\text { The tumour was the size of a walnut, and occupied the } \\
\text { superior part of the breast. No skin was removed, but that } \\
\text { immediately covering the disease sloughed. }\end{array}$ \\
\hline
\end{tabular}

Plastic Operations.

\begin{tabular}{|c|c|c|c|c|c|}
\hline No. & $\begin{array}{l}\text { Sex } \\
\text { and } \\
\text { age. }\end{array}$ & Operator. & Nature of operation. & $\begin{array}{c}\text { Stay in } \\
\text { Hospital } \\
\text { after } \\
\text { operation. }\end{array}$ & Result. \\
\hline 1 & M. 23 & Mr. Teale & $\begin{array}{l}\text { Plastic operation } \\
\text { for deformity of the } \\
\text { nose. }\end{array}$ & 18 days & $\begin{array}{l}\text { Considerable } \\
\text { relief of de- } \\
\text { formity. }\end{array}$ \\
\hline 2 & F. 1 & Mr. Teale & $\begin{array}{l}\text { Plastic operation } \\
\text { for siugle hare-lip. }\end{array}$ & 10 days & $\begin{array}{l}\text { Union com. } \\
\text { plete. }\end{array}$ \\
\hline 3 & M. 23 & Mr. P. Teale & $\begin{array}{l}\text { Rhinoplastic oper- } \\
\text { ation. }\end{array}$ & 68 days & $\begin{array}{l}\text { Recovery, with } \\
\text { great relief of } \\
\text { deformity. }\end{array}$ \\
\hline
\end{tabular}
Remarks.
The deformity had resulted from syphilitic ulceration of
the right ala and septum two years before, and consisted
of a puckered and shrivelled right ala, a depressed tip, and
a widely expanded but flattened left ala. The middle third
of the right ala was cut away, and into the gap thus formed
a quadrilateral flap, attached by its base superiorly and
raised from the cheek, was transplanted and fixed there by
wire sutures. The whole flap lived and united, and thus
the two sides of the nose were made symmetrical.
'The cleft was on the left of the median line, did not ex-
tend through the entire lip, and was confined to that
situation.
The nose had been greatly disfigured by syphilitic dis.
ease; and, before his admission, attempts at relief had
been made on two occasions by plastio operations, consisting of the separation of the remains of the alæ from the nasal bones to form the tip, and the filling of the resulting gap by two large quadrilateral flaps dissected up from the cheeks, and subsequently the formation of a septum froin the centre of the upper lip. The result was not satisfactory. The nose was made up of a series of flattened patches, separated by deep cicatricial lines, was broad, short, and flat. The surface of the central portion having been pared away, the usual shaped piece of integument, taken from the forehead and left attached by a broad base at the left inner canthus, was turned down and fastened by sutures in the normal position of the nose. The whole lived and united. Subsequently canthus, was turned down and fastened by sutures in the normal position of the nose. The whole lived and united. Subsequently,
the deep lines of cicatrix above mentioned were dissected out, and the edges of the wounds brought into careful appusition, by which the deep lines of cicatrix above mentioned were dissected out, and the edges of the wounds brought into careful appusition, by which
means direct union was obtained almost without any marking. When discharged, and when seen some months later, the nose presented a very shapely appearance. See No. 3, Removal of Eyeball.

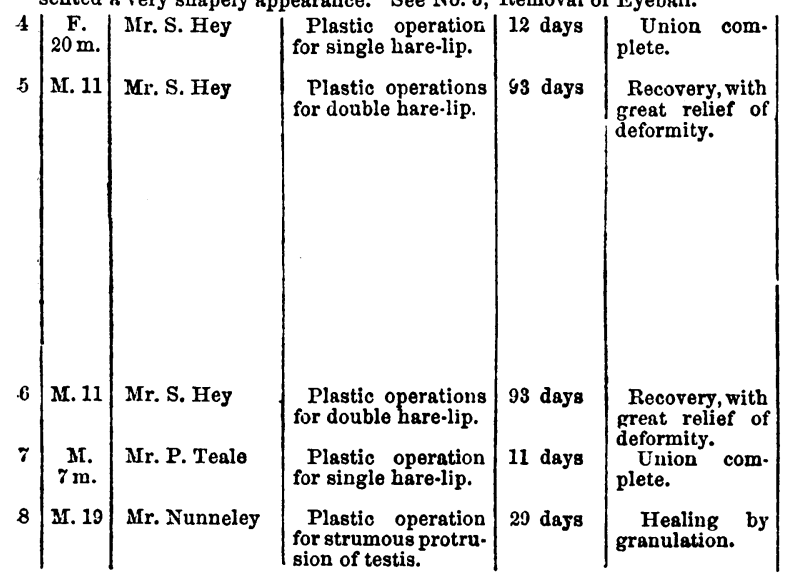

rapidly rexpestire gland. After the spreading had been arrested, the wound for a time quickly healed; but when the protruding mass had reached the dimensions of half a hen's egg, cicatrisation ceased. The scrotum was dissected up all round the raw surface, and the two edges drawn over the testis, retained in apposition by hare-lip pins. Union did not take place, but the wound afterwards healed with considerable rapidity; and, on his discharge, was healthy, and about the size of half-a.crown.

The cleft extended through the right side of the lip and alveolus, and did not reach the palate. Union by the first intention was perfect.

was wide, and extended thy was unusually great; the clef the ceede, and extended through hard and soft palates; and the ceatral portion of the jaw, with attached lip and fron

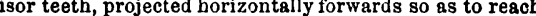
neyond the tip of the nose. The operations were performed on three separate occasions. 1. The projecting portion of alveolus with incisor teeth was removed, having been previously detached from the central piece of lip. 2 The middle portion being ignored, the whole cleft was closed, as in ordinary single hare-lip, by bringing together the pared edges of the two lateral pieces of lip. 3. The edges, tip, and under surface of the central piece, were pared, aud the remaining portion bent backwards, and so retained by plaister, as to unite with the pared edge of the septum nasi. All the operations succeeded perfectly.

This patient was the twin brother of the above. Their cases were exactly alike, the operations were of a similar kind, and in both cases the results were equally good.

The cleft was on the left of the middle line, and extended through the entire palate. The line of union was complete.

The left testis had been the seat of strumous inflamma- 
Operations for the Removal of Cataract.

\begin{tabular}{|c|c|c|c|c|c|c|}
\hline No. & $\begin{array}{l}\text { Sex } \\
\text { and } \\
\text { age. }\end{array}$ & Operator. & Nature of operation. & $\begin{array}{l}\text { Stay in } \\
\text { Hospital } \\
\text { after } \\
\text { operation. }\end{array}$ & Result. & Remarks. \\
\hline 1 & M. 69 & Mr. Smith & $\begin{array}{l}\text { Extraction of hard } \\
\text { cataidact. }\end{array}$ & 23 days & $\begin{array}{l}\text { Curea. Could } \\
\text { see to read } \\
\text { small print. }\end{array}$ & $\begin{array}{l}\text { The left lens had been previously extracted. On this } \\
\text { occasion, the right lens was removed. In both eyes a } \\
\text { little prolapse of iris took place, but vision in both was } \\
\text { very good. }\end{array}$ \\
\hline 2 & F. 66 & Mr. P. Teale & $\begin{array}{l}\text { Extraction of left } \\
\text { hard cataract. }\end{array}$ & 18 days & $\begin{array}{l}\text { Cured. Cornea } \\
\text { hazy when dis. } \\
\text { charged, but } \\
\text { afterwards she } \\
\text { was able to read }\end{array}$ & $\begin{array}{l}\text { The right lens was still healthy enough to enable her to } \\
\text { read large print. The left lens was quite opaque. A con- } \\
\text { siderable amount of pain, accompanied by prolapse of iris } \\
\text { and some inflammation of cornea, followed; but soon } \\
\text { yielded to treatment. }\end{array}$ \\
\hline 3 & F. 68 & Mr. P. Teale & $\begin{array}{l}\text { Extraction of right } \\
\text { hard cataract. }\end{array}$ & 30 days & $\begin{array}{l}\text { Cured. When } \\
\text { discharged she } \\
\text { could not count } \\
\text { fingers, owing } \\
\text { to slight opacity } \\
\text { of cornea, but } \\
\text { afterwards im. } \\
\text { proved, so as to } \\
\text { be able to read } \\
\text { No. } 1 \text { Juger. }\end{array}$ & $\begin{array}{l}\text { Both lenses were opaque. The right cataract only, how- } \\
\text { ever, was removed on this occasion. Prolapse of iris and } \\
\text { inftamed cornea, attended by considerable suffering, as in } \\
\text { last case, followed. }\end{array}$ \\
\hline 4 & X. 42 & Mr. S. Hey & $\begin{array}{l}\text { Extraction of hard } \\
\text { cataract. }\end{array}$ & 20 days & $\begin{array}{l}\text { Cured. Pro. } \\
\text { lapse of iris. } \\
\text { Clear and large } \\
\text { pupil. }\end{array}$ & $\begin{array}{l}\text { The left lens only was opaque. A little conjunctival in- } \\
\text { flammation followed the operation. Owing to the state of } \\
\text { this patient's mind, it was impossible accurately to test } \\
\text { vision. That he recovered so much as to enable him to } \\
\text { see the people around, was, however, manifest. In the fol- } \\
\text { lowing month, he returned with right cataract, which was } \\
\text { removed by extraction, with result similar to that in the } \\
\text { left eye. }\end{array}$ \\
\hline 5 & F. 9 & Mr. Wheelhouse & $\begin{array}{l}\text { Tearing up of cap. } \\
\text { sular cataract. }\end{array}$ & 4 days & $\begin{array}{l}\text { Slight improve- } \\
\text { ment of sight. }\end{array}$ & $\begin{array}{l}\text { She had been born with left cataract. The lens had been } \\
\text { torn up on several occasions, both at this hospital and else- } \\
\text { where. Thick opaque capsule only remained. This Mr. } \\
\text { Wheelhouse tore up. When seen some weeks afterwards, } \\
\text { there was still a considerable amount remaiuing, but she } \\
\text { was able to see large objects. }\end{array}$ \\
\hline 6 & F. $2 S$ & Mr. S. Hey & $\begin{array}{l}\text { Removal of cata- } \\
\text { racts by suction. }\end{array}$ & 42 days & $\begin{array}{l}\text { Cured. Able to } \\
\text { read No.1.Jäger } \\
\text { with right eye, } \\
\text { and with left } \\
\text { No. } 4 \text { Jäger. }\end{array}$ & $\begin{array}{l}\text { was able to see } \\
\text { The right lens had been opaque four years, and the left } \\
\text { two years. The lenses were on separate occasions removed } \\
\text {-each at one sitting-by Mr. Pridgin Teale's suction- } \\
\text { curette. A portion of the left lens, which was transparent, } \\
\text { escaped observation, and was left; in consequence of which, }\end{array}$ \\
\hline 7 & F. 16 & Mr. S. Hey & $\begin{array}{l}\text { Removal of cata- } \\
\text { riacts by suction. }\end{array}$ & 85 days & $\begin{array}{l}\text { Cured. Ex- } \\
\text { cellent vision, } \\
\text { which could not, } \\
\text { however, be tes- } \\
\text { ted, owing to } \\
\text { her inability to } \\
\text { read. }\end{array}$ & $\begin{array}{l}\text { a little intlammation followed. Both pupils were perfect. } \\
\text { The cataracts had rapidly appeared during the month } \\
\text { previous to her admission, in consequence of diabetes, } \\
\text { from which she had been suffering for four months. The } \\
\text { cataracts were completely removed-each at one sitting- } \\
\text { as in the case last reported. Her recovery was made with- } \\
\text { out any drawback. The length of her stay in the hospital } \\
\text { was caused by the treatment necessary for the relief of the }\end{array}$ \\
\hline 8 & F. 64 & Mr. P. Teale & $\begin{array}{l}\text { Extraction of hard } \\
\text { cataract. }\end{array}$ & 21 days & $\begin{array}{l}\text { Cured, Reads } \\
\text { No. } 1 \text { Jäger. }\end{array}$ & $\begin{array}{l}\text { The right lens had been previously extracted, with an } \\
\text { excellent result. }\end{array}$ \\
\hline
\end{tabular}

Partial or Complete Removal of the Eyeball.

\begin{tabular}{|c|c|c|c|c|c|}
\hline No. & $\begin{array}{l}\text { Sex } \\
\text { and } \\
\text { age. }\end{array}$ & Operator. & Nature of operation. & $\begin{array}{c}\text { Stuy in } \\
\text { Hospital } \\
\text { after } \\
\text { operation. }\end{array}$ & Fesult. \\
\hline 1 & M. 30 & Mr. Smith & $\begin{array}{l}\text { Fxcision of eye } \\
\text { ball. }\end{array}$ & 10 days & Recovery. \\
\hline 2 & M. 15 & Mr. Smith & $\begin{array}{l}\text { Abscission of eye- } \\
\text { ball. }\end{array}$ & 22 days & Recovery. \\
\hline 3 & M. 23 & Mr. P. Teale & $\begin{array}{l}\text { Excision of eye- } \\
\text { ball. }\end{array}$ & $\begin{array}{l}\text { See No. } 3 \\
\text { of Plastic } \\
\text { Opera. } \\
\text { tions. }\end{array}$ & Recovery. \\
\hline
\end{tabular}

Remarks.

A piece of metal had become deeply imbedded in the right eye five months before. Complete loss of vision in that eye, continued severe pain, and subsequent failure of sight in the left eye, resulted. After the right eye had been extirpated, vision was rapidly restored in the left. At the fundus of the right eye was found a piece of steel the size of a threepenny coin.

Vision of the left eye was beginning to fail, in consence, it was presumed, of irritation caused by the presence of a diseased right globe, which had become the seat of a large staphyloma after a wound when he was jour years ald. Abscission, as recently brought before the profession at inoorfields IHospital, was performed. A considerable amount of inflammation, atteuded by constitutional disturbance, followed; but these in a short time were subdued, and an excellent moveable stump resulted. When he left the hospital, the left eye had quite recovered.

This patient is the same as that reported at No. 3, Plastic Operations (see preceding page). When five years old, he received a blow on his left eye; inflammation and complete loss of sight followed. The injured eye had been subject to occasional attacks of inflammation from slight causes ever afterwards; and for some months prior to his admission into the J,eeds Infirmary, the sight of the right eye was beginning to be impaired. In the left eve the jris was universally adherent to a shrivelled chalky lens, and the globe was tender. The right iris was slightly adherent bebind. Mr. P. Teale first performed iridectomy on the left eye, and removed the degenerated lens. Sunpurative inflammation set in, and excision was, therefore, at once performed. Sight of right eye improved much during his stay in hospital.

4 Mr. 40| Mr. Nunveley | Fxcision of eye- 5 days ball.

The eye had been ruptured extensively in its anterior surface by a blow. In spite of treatment, suppurative inflammation was threatening, when the globe was removed. All pain and constitutional symptoms ceased at once. 